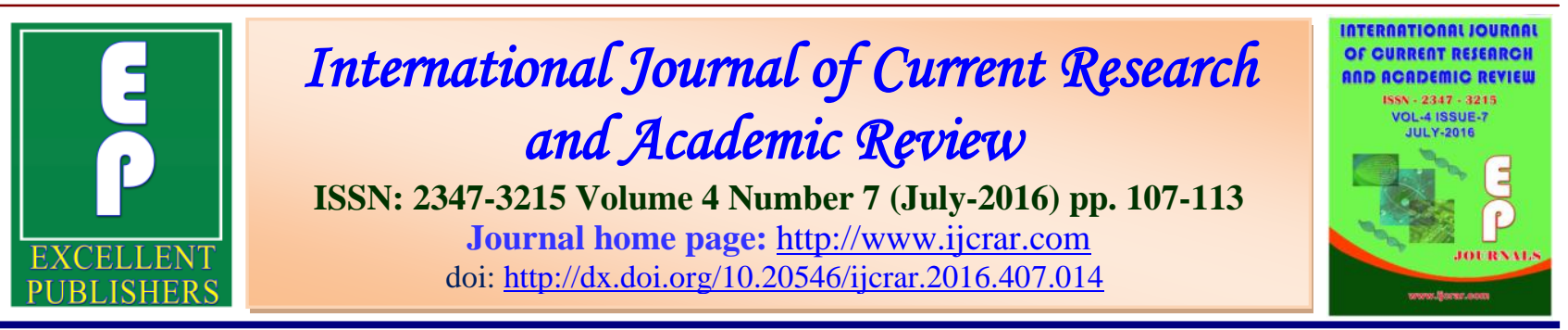

\title{
Diversity Indices of Fresh Water Crustacean Zooplankton
}

\author{
P.G. Dube ${ }^{1 *}$, S.D. Shelar ${ }^{2}$, S.S. Mokashe ${ }^{1}$ and S.S. Shinde ${ }^{3}$ \\ ${ }^{1}$ Dr.Babasaheb Ambedkar Marathwada University, Aurangabad, (M.S.) India \\ ${ }^{2}$ L.B.S.Senior College, Partur, Tq. Partur, Dist. Jalna, (M.S.) India \\ ${ }^{3}$ Vivekanand College, Aurangabad, (M.S.) India \\ *Corresponding author
}

\section{KEYWORDS}

Diversity indices, fresh water, crustacean zooplankton.

\section{A B S T R A C T}

Diversity index is a mathematical measure commonly used as an indicator of the interpretation of the environmental status, as well as to measure the average degree of uncertainty of occurrence of a particular species. Therefore, Simpson's, Shannon-Weiner, Richness and Evenness diversity indices incorporated in the present study. The objective of the study was to determine the diversity indices of crustacean zooplankton (Copepoda, Cladocera and Ostracoda) from Upper Dudhana dam. Result showed that Simpson's index was maximum (0.818) in Copepods and minimum (0.644) in ostracods. Shannon-Weiner index was highest (1.586) in copepoda whereas lowest (0.412) in ostracoda. Evenness was maximum (0.969) in copepoda and minimum (0.503) in ostracoda. Richness index was maximum (4) in copepoda and minimum (1) in ostracoda. It is concluded that, in the present investigation out of total crustacean zooplankton copepoda is more diverse group whereas ostracoda poorly contributed as compared to the other two groups.

\section{Introduction}

Crustacea is the class of phylum 'Arthropoda' consisting three major groups of zooplankton i.e. Copepoda, Cladocera and Ostracoda. They are tiny aquatic animals and plays key role in a food chain of fishes. They mostly feed on unicellular plants and animals, small metazoans especially other crustaceans as well as organ debris. Planktonic copepods have high nutritive value because of their protein content (Altaff and Chandran, 1989) essential amino acids (Kraul et al., 1993) which greatly enhance their value as live feed in aquaculture. From the ecological point of view cladocera is a crucial group among zooplankton community. Ostracods have a ubiquitous distribution, high diversity of life history strategies. These characteristics make the group useful study tool in multiple disciplines. The most stable 
communities have large numbers of species which are fairly evenly distributed in goodsized populations. Pollution often reduces diversity by favouring a few dominant species. Diversity is therefore a factor in successful conservation management. Hence the application of the diversity indices is essential to measure crustacean zooplankton diversity.

Use of different diversity indices continue to elevate disagreement among the naturalists, whether there is exist a biological relationship between them or not (Auclair and Goff, 1971; Risser and Rice, 1971). Early researchers interpret their results as the number of species per sample or per liter as an index of their diversity. However, such a procedure does not help in distinguishing the relative abundance in terms of community structure of the different species besides other characteristics. The diversity cannot be estimated just by one index (Hayek and Buzas, 1997; Purvis and Hector, 2000), therefore, to overcome these limitations different diversity indices such as Simpson's, Shannon-Weiner, Evenness and richness was used in the present study.

The value of Simpson's index (D) ranges between 0 and 1.With this index, 0 represents infinite diversity and 1, no diversity. Generally Simpson's index gives more weight to the more abundant species in a sample. The addition of rare species to a sample causes only small changes in the value of $\mathrm{D}$. Shannon-Wiener diversity index (H) varies from 0 to 5 . This index provide more information than simply the number of species present (i.e., they account for some species being rare and others being common), they serve as valuable tools that enable biologists to quantify diversity in a community and describe its numerical structure. Diversity indices are important statistical measure used to characterize richness (the number of species) and evenness (how uniform abundant species are in a sample) of the species in the community (Magurran, 1988). The number of species per sample is a measure of richness $(\mathrm{S})$ and Evenness (E) expresses how evenly the individuals in a community are distributed among the different species. As species richness and evenness increase, so diversity increases. It is used as a tool for determining the health of an ecosystem (Schmitz and Nadel, 1995; Guerold, 2000).

\section{Materials and Methods}

\section{Study area}

The 'Upper Dudhana dam' is constructed on the Dudhana River near village Somthana in Badnapur tahsil of Jalna district, Maharashtra. This is an earthen dam located at $19^{\circ} 55^{\prime} 11.8 " \mathrm{~N}$ to $75^{\circ} 41^{\prime} 39.9^{\prime \prime} \mathrm{E}$. The dam has a height of about $18 \mathrm{~m}$ and $2.75 \mathrm{~km}$ in length, wherein the width is approximately 2 $\mathrm{km}$.

\section{Zooplankton Collection, Preservation, Identification and Density Analysis}

The samples of zooplankton were collected from each selected study site of the dam during 7am to 9am for a period of one year (June 2013 to May 2014). The nylon net ( $40 \mu$ mesh size) was used for collection of zooplankton. Collection of each sample done by filtering 100 lit of water and concentrate to the $50 \mathrm{ml}$ and transferred to the plastic bottles, it was carefully labeled and preserved immediately onsite using $4 \%$ formalin. Later, the collected samples were brought to the laboratory for identification using various monographs, books and other published literature (Altaff, 2004, Edmondson, 1958 and Pennak, 1978). After an accurate identification of each species, the density of zooplankton was calculated as 
per the Lackey's drop count method (Lackey, 1938).

Formula used for the calculation of population density:

$\mathrm{N}=\mathrm{n} \times \mathrm{v} / \mathrm{V}$

Where,

$\mathrm{N}=$ Total no. of organisms/ lit of water filtered.

$\mathrm{n}=$ Number of zooplankton counted in $1 \mathrm{ml}$ of plankton sample.

$\mathrm{v}=$ Volume of concentrated plankton sample in $\mathrm{ml}$.

$\mathrm{V}=$ Volume of total water filtered through in lit.

\section{Statistical analysis}

Simpson's Index (D)

$\mathrm{D}=\sum_{i=1}^{s}(\mathrm{ni} / \mathrm{n}) 2$

Where,

$\mathrm{D}=$ Simpson's index

ni $=$ Total population of $i^{\text {th }}$ species in community

$\mathrm{n}=$ Total population of all species in community

Shannon-Weiner Index (H)

$H=\sum_{\mathrm{i}=1}^{\mathrm{s}}[(\mathrm{ni} / \mathrm{n}) \ln (\mathrm{ni} / \mathrm{n})]$

Where,

$\mathrm{H}=$ Shannon-Weiner index

$\mathrm{S}=$ Number of individuals of each species

ni $=$ Total population of $i^{\text {th }}$ species in community

$\mathrm{n}=$ Total population of all species

\section{Evenness Index (E)}

$\mathrm{E}=\mathrm{H} / \ln (\mathrm{S})$
Where,

$\mathrm{E}=$ Evenness index

$\mathrm{H}=$ Shannon-Weiner index

$\mathrm{S}=$ Number of individuals of each species

\section{Richness Index (S)}

$\mathrm{S}=\mathrm{N}-1 / \ln (\mathrm{n})$

Where,

$\mathrm{S}=$ Richness index

$\mathrm{N}=$ Total no. of species in a community

\section{Results and Discussion}

Crustacean zooplankton population density (org/lit) is depicted in Table.1 and their corresponding diversity indices are in Table.2.

Copepoda: Monthly population densities of copepoda during the study were maximum (38.88 org/lit) in the month of July and minimum (3.38 org/lit) in February. Simpson index was maximum $(0.818)$ in the month of May whereas minimum (0.127) in the month of February. Which indicated that the highest density of copepod in May and lowest in February. Simpson diversity index (D) is always higher where the community is dominated by less number of species and less when the dominance is shared by large number of species (Whittaker, 1965). Shannon-Weiner index $(\mathrm{H})$ was maximum (1.586) in January and minimum (0.352) in May. Species diversity measured by Shannon Weiner index $(\mathrm{H})$ is directly proportional to the number of species in the sample and the uniformity of the species distribution in the total abundance (Krebs, 1996). As a nature of copepod they prefer eutrophic environment to grow in high number that was observed in the present study. Evenness index (E) was maximum 
$(0.969)$ in January and minimum (0.215) in May. Species Evenness was comparatively high in January showing a decline in the copepod diversity during this period. This might because of the changing dam water parameters, which showed in my earlier work (Dube et al., 2016). The simplest and most frequently used measure of biological diversity is species richness $(\mathrm{S})$, the number of species per unit area. A vast amount of ecological research has been undertaken using species richness as a measure to understand what affects, and what is affected by, biodiversity. In the present study species richness index was maximum (4) in the month of July to November, January and March whereas minimum (2) in the month of May. It means the copepod diversity was highest in rainy and winter months whereas lowest in summer months.

Cladocera: Monthly population density of cladocera during the study was maximum (32.25 org/lit) in the month of July and minimum (1.25 org/lit) in January. Simpson index (D) was maximum (0.676) in the month of May whereas minimum (0.2) in the month of November. High ' $D$ ' value indicated high density and low value indicates low density of cladocera. Similar findings were recorded by Ndebele Murisa
(2012), Koli and Muley (2012) and Balakrishna et al., (2013). Shannon-Weiner index $(\mathrm{H})$ was maximum (1.424) in April and minimum (0.636) in February. It means diversity of cladocera was highest in April and it was lowest in February. Padhye and Dahanukar (2015) reported similar result from Mula dam, Aundh, Pune (M.S.), India. Evenness index (E) is maximum (0.87) in April and minimum (0.389) in February. The high evenness was due to the more diversity and species richness. When the dominance is more the species richness and evenness is less which might be due to representation of few species and its numerical dominance. The similar observation also made by Vanjare (2010) and it is corroborating the present findings. Richness index (S) of cladocera was maximum (4) in the month of April whereas minimum (2) in the months of June to August, January, February and May. It means the diversity of cladoceran was high in April. The diversity index values revels that the dam water with good environmental condition and less anthropogenic activity in April because the cladoceran prefers mostly good quality water. Similar observation made by Koli and Muley (2012) and Ndebele Murisa (2012).

Table.1 Monthly zooplankton group population density (org/lit) from Upper Dudhana dam during June 2013 to May 2014

\begin{tabular}{|r|c|c|c|c|c|c|c|c|c|c|c|c|}
\hline $\begin{array}{c}\text { Zooplankton } \\
\text { Group }\end{array}$ & Jun & Jul & Aug & Sept & Oct & Nov & Dec & Jan & Feb & Mar & Apr & May \\
\hline COPEPODA & 30.25 & 38.88 & 19.75 & 12.22 & 17.38 & 17.13 & 3.58 & 11.88 & 3.38 & 10.67 & 14 & 8.5 \\
\hline CLADOCERA & 26.25 & 32.25 & 18.25 & 8.25 & 6.75 & 3.5 & 5.17 & 1.25 & 13.8 & 17.96 & 14.59 & 19.5 \\
\hline OSTRACODA & 1.25 & 0 & 0.5 & 0.5 & 0.82 & 0 & 1.5 & 0.25 & 2.25 & 1 & 0 & 0.25 \\
\hline $\begin{array}{r}\text { Total } \\
\text { zooplankton }\end{array}$ & $\mathbf{5 7 . 7 5}$ & $\mathbf{7 1 . 1 3}$ & $\mathbf{3 8 . 5}$ & $\mathbf{2 0 . 9 7}$ & $\mathbf{2 4 . 9 5}$ & $\mathbf{2 0 . 6 3}$ & $\mathbf{1 0 . 2 5}$ & $\mathbf{1 3 . 3 8}$ & $\mathbf{1 9 . 4 3}$ & $\mathbf{2 9 . 6 3}$ & $\mathbf{2 8 . 5 9}$ & $\mathbf{2 8 . 2 5}$ \\
\hline
\end{tabular}

*Monthly values are average of four sampling sites. 
Int.J.Curr.Res.Aca.Rev.2016; 4(7): 107-113

Table.2 Monthly zooplankton group diversity indices of Upper Dudhana Dam during June 2013 to May 2014.

\begin{tabular}{|c|c|c|c|c|c|c|c|c|c|c|c|c|c|}
\hline $\begin{array}{l}\text { Diversity } \\
\text { Indices }\end{array}$ & Jun & Jul & Aug & Sept & Oct & Nov & Dec & Jan & Feb & Mar & Apr & May & Average \\
\hline \multicolumn{14}{|c|}{ COPEPODA } \\
\hline $\begin{array}{l}\text { Simpson's } \\
\text { Index (D) }\end{array}$ & 0.382 & 0.489 & 0.393 & 0.224 & 0.437 & 0.421 & 0.136 & 0.203 & 0.127 & 0.290 & 0.446 & 0.818 & 0.364 \\
\hline $\begin{array}{l}\text { Shannon- } \\
\text { Weiner Index } \\
(\mathrm{H})\end{array}$ & 1.163 & 1.018 & 1.172 & 1.536 & 1.096 & 1.234 & 1.209 & 1.586 & 1.191 & 1.360 & 0.905 & 0.352 & 1.152 \\
\hline Evenness(E) & 0.711 & 0.622 & 0.716 & 0.939 & 0.670 & 0.754 & 0.739 & 0.969 & 0.728 & 0.831 & 0.553 & 0.215 & 0.704 \\
\hline Richness(S) & 3.000 & 4.000 & 4.000 & 4.000 & 4.000 & 4.000 & 3.000 & 4.000 & 3.000 & 4.000 & 3.000 & 2.000 & 3.500 \\
\hline \multicolumn{14}{|c|}{ CLADOCERA } \\
\hline $\begin{array}{l}\text { Simpson's } \\
\text { Index (D) }\end{array}$ & 0.481 & 0.536 & 0.479 & 0.361 & 0.375 & 0.200 & 0.459 & - & 0.618 & 0.414 & 0.270 & 0.676 & 0.443 \\
\hline $\begin{array}{l}\text { Shannon- } \\
\text { Weiner Index } \\
\text { (H) }\end{array}$ & 0.818 & 0.758 & 0.809 & 1.104 & 1.072 & 1.128 & 0.918 & 0.794 & 0.636 & 1.096 & 1.424 & 0.682 & 0.937 \\
\hline Evenness(E) & 0.500 & 0.463 & 0.495 & 0.675 & 0.655 & 0.689 & 0.561 & 0.486 & 0.389 & 0.670 & 0.870 & 0.417 & 0.572 \\
\hline Richness(S) & 2.000 & 2.000 & 2.000 & 3.000 & 3.000 & 3.000 & 3.000 & 2.000 & 2.000 & 3.000 & 4.000 & 2.000 & 2.583 \\
\hline \multicolumn{14}{|c|}{ OSTRACODA } \\
\hline $\begin{array}{l}\text { Simpson's } \\
\text { Index (D) }\end{array}$ & 1.000 & - & 1.000 & 1.000 & 1.000 & - & 1.000 & 1.000 & 0.644 & - & - & 1.000 & 0.956 \\
\hline $\begin{array}{l}\text { Shannon- } \\
\text { Weiner Index } \\
\text { (H) }\end{array}$ & 0.000 & 0.000 & 0.000 & 0.000 & 0.000 & 0.000 & 0.000 & 0.000 & 0.412 & 0.000 & 0.000 & 0.000 & 0.034 \\
\hline Evenness(E) & 0.000 & 0.000 & 0.000 & 0.000 & 0.000 & 0.000 & 0.000 & 0.000 & 0.503 & 0.000 & 0.000 & 0.000 & 0.042 \\
\hline Richness(S) & 1.000 & 0.000 & 1.000 & 1.000 & 1.000 & 0.000 & 1.000 & 1.000 & 2.000 & 0.000 & 0.000 & 1.000 & 0.750 \\
\hline
\end{tabular}

Ostracoda: Monthly population density of ostracoda was maximum $(2.25 \mathrm{org} / \mathrm{lit})$ in the month of February and minimum $(0.25$ org/lit) in the months of January, February and May, whereas ostracods were not noticed in the month of July, November and April. Simpson index (D) was maximum (1) in the month of June, August, September, October, December, January and May whereas minimum (0.644) in the month of February. Similar observation also found by Balakrishna et al., (2013). In the present study high diversity values of Simpson diversity clearly stated that the selected dam is not cross the permissible limit of pollution according to value set by APHA (1992). Shannon-Weiner index $(\mathrm{H})$ was maximum
(0.412) in February and minimum (0) in all the months of year except February. It means the diversity of ostracod was very low. The abundance decline due to connection with redistribution of number of individuals in water body or less possibility to stay in the euphotic zone where photosynthesis occurred (Talling, 1986). Evenness index (E) is maximum (0.503) in February and minimum in all remaining months of year. These observations indicate that, pollution load fluctuates in different months due to several factors such as the volume of water, density of biota, the quantity and quality of domestic sewage. Pandit et al., (2007) stated that poor number of ostracods in Pravara river in 
Ahmednagar, Maharashtra. Richness index (S) of ostracoda was maximum (2) in the month of February whereas minimum (1) in the months of June, August, September, October, December, January and May. It indicated that the ostracod diversity was maximum in February and minimum in rainy and winter months. Similar observation made by Mahor (2011) who observed the maximum population of ostracoda in February month and minimum in winter months.

In the present investigation the values of diversity indices tells us that, the dam water environment is not uniform during the study period so population density of crustacean zooplanktons always fluctuated along with the changing environmental factors.

\section{Conclusion}

In the present study copepoda and cladocera have high diversity indices values for stable communities while the unstable one i.e. ostracoda have low values. The finding of the present study therefore shows that Simpson and Shannon-Weiner diversities increase as richness increase. And for a given pattern of evenness and richness they do not always follow the same trend. Simpson diversity is less susceptible to richness and more sensitive to evenness than Shannon-Weiner index.

\section{Acknowledgement}

Thanks to the Prof. Y. K. Khillare and The Head, Prof. C.J. Hiware, Department of Zoology, Dr. Babasaheb Ambedkar Marathwada University, Aurangabad for providing necessary laboratory facility for the completion of this research work.

\section{References}

Acharjee, B., A. Dutta, M. Chaudhury and B. Pathak. 1995. Phytoplankton species diversity indices in dighali beel, Assam. India Environ. Ecol., Vol.13(3), pp.660-662.

Adesalu, T.A. and Nwankwo, D.I. 2008. Effect of water quality indices on phytoplankton of a Sluggish tidal creek in Lagos, Nigeria. Pakistan $J$. Biol. Sci., 11, pp.836-844.

Altaff, K. 2004. A manual of Zooplankton, Department of Zoology, The New College, Chennai, pp.19-145.

Altaff, K. and Chandran, M.R. 1989. Sexrelated biochemical investigation of the diaptomid Heliodiaptomus viduus (Gurney) (Crustacea:Copepoda). Proc.Indian Sci. Acad., (Animal Sci.), Vol.98, pp.175-179.

APHA. 1992. Standard Methods for the Examination of Water and Wastewater. 18th ed. American Public Health Association (APHA), American Water Works Association (AWWA) and Water Pollution Control Federation (WPCF), Washington, DC.

Balakrishna, D., Mahesh, T., Samatha, D. and Ravinder, Reddy T. 2013. Zooplankton diversity indices of Dharmasagar lake, Warangal district (A.P.), Int. J. Res. Biol. Sci., Vol.3(3): pp.109-111.

Dube, P.G., Shelar, S.D. and Mokashe, S.S. 2016. Correlation between Brachionus calyciforus and Brachionus falcatus with physico-chemical parameters of Upper Dudhana Dam. Int. J. Recent Scientific Res., (IJRSR), Vol.7 (2), pp. 8915-8919.

Edmondson, W.T. 1958. Freshwater Biology, Second Ed. John Wiley and Sons Inc. London-Chapman and Hall Limited, New York, USA, 1248.

Hayek, L.C. and Buzas, M.A. 1997. Surveying Natural Populations. Columbia University Press, New York. Purvis and Hector, 2000. 
Koli, K.B and D.V. Muley. 2012. Study of zooplankton diversity and seasonal variation with special reference to physico-chemical parameters in tulshi reservoir of Kolhapur district (M.S.), India. Int. Sci. Res. J., Vol. 4(1): pp.67-71.

Kraul, S.H., Brittain, K., Cantrell, R. and Nagao, T. 1993. Nutritional factors affecting stress resistance in the larval mahimahi, Coryphaena hippurus. J.world Aquacul. Soc., Vol.24, pp.186193.

Krebs, C.J. 1996. "Ecology: The Experimental Analysis of Distribution and Abundance," Harper Intel, Lectual Ed., New York.

Lackey, R., Nlewadim, A. and Adeyemo, A. 1998. Effect of Inorganic fertilization on zooplankton production in Brackish water (ed.). Selected papers from 9th/10th Annual Conference of the Nigerian Association for Aquatic Sciences. Theme: Sustainable Utilization of Aquatic/Wetland Resources, held at University of Agriculture Abeokuta, Ogun state, Nigeria, 30th November-2nd December, 1995, pp.75-82.

Magurran, A.E. and McGill, B.J. 2011. Challenges and opportunities in the measurement and assessment of biological diversity. In:Magurran, A. E. and McGill, B. (Eds). Biological Diversity: Frontiers in measurement and assessment. Oxford University Press Oxford, pp.1-7.
Ndebele, M.M.R. 2012. Biological monitoring and pollution assessment of the Mukuvisi River, Harare, Zimbabwe. Lakes and Reservoirs: Res. Management, Vol.17, pp.73-80.

Nduka, J.K., Orish Ebere Orisakwe, Linus Obi EzenwekeBalakrishna, D., Mahesh, T., Samatha, D. and Ravinder, Reddy, T. 2013. Zooplankton diversity indices of Dharmasagar lake, Warangal district (A.P.)., Int. J. Res. Biol. Sci., Vol.3(3): pp.109-111.

Pandit, S.V., Vaidya, V.V. and Joshi, P.P. 2007. Studies on zooplankton diversity of Pravara river, near Sangamner city, Dist, Ahmednagar, Maharashtra. J. Aqua. Biol., Vol.22(2), pp.33-38.

Pennak, R.W. 1953. Fresh Water Invertebrates of the United States.

Schmitz, A., Nadel, R. 1995. Influence of 3,4-dichloroaniline (3,4-DCA) on benthic invertebrates in indoor experimental streams. Ecotoxicol. Envir. Safety, Vol. 30, pp.6371.Guerold, 2000)

Talling, J.F. 1986. Origin of stratification in an African Rift lake. Limnol. Oceanogr. 8: Hydrobiologia, pp.138139.

Whittaker, R.H. 1965. Dominance and diversity in land plant communities. Science (Washington, D.C.), Vol.147, pp.250-260.

\section{How to cite this article:}

Dube, P.G., S.D. Shelar, S.S. Mokashe and Shinde, S.S. 2016. Diversity Indices of Fresh Water Crustacean Zooplankton. Int.J.Curr.Res.Aca.Rev.4(7): 107-113.

doi: http://dx.doi.org/10.20546/ijcrar.2016.407.014 